\title{
$\mathrm{EFD} / \mathrm{JFL}$
}

Edebiyat Fakültesi Dergisi / Journal of Faculty of Letters

Cilt/Nolume 29 Sayı/Number 1 (Haziran/June 2012)

\section{Convergence and Divergence in the Interpretation of Quranic Polysemy and Lexical Recurrence*}

Kur'an'daki Çokanlamlı Sözcükler ve Sözcüksel Yinelemelerin Çevirisinde Dil Benzeşmesi ve Ayrışması

Jamal ALQINAI*

$\ddot{O}_{z}$

Kur'an çevrilirken eşanlamlı sözcüklerin kullanımı kutsal metnin farklı yorumlarına ve farklı çevirilerine yol açan sıkıntılı bir konudur. Çevirmen hatasız ve profesyonel olmaya gayret etse de, Kur'an çevirileri hatalarla ve vurgu mekanizmasına özgü anlamsal-sözdizimsel belirsizlik, bürünsel (vezin tekniğine dair), işitimsel, özel sözbilimsel doku örgüsü ve kültüre ilişkin göndermelerden dolayı her zaman hassas teolojik, kültürel ve tarihsel çağrışımların anlamlarının çarpıtılması ile dolu olmuştur. Bu sebepten ötürü Kur'an'ın İngilizce çevirilerinin çoğunda eşdeğer olmama ve çevrilememe durumları ile geniş kapsamlı anlam belirsizlikleri, anlaşılmazlık ve belirgin olmayan sınırlar daha sık görülecektir. Bugüne kadar eğilim, Kur'an'ın söylemi hakkında yorum ve açıklamaları temel alan tefsire dayalı çeviriyi kabul etmek olmuştur. Tefsir konusunda belirli bir kitap olmadığından, çeviriler Arapça bilmeyen Müslümanlara yönelik açıklamalar veya yakın ifadeler olarak düşünülür. Bu çalışma özellikle farklı Kur'an çevirmenlerinin Kur'an'daki çokanlamlı sözcükleri anlatmak için eşanlamlı sözcükleri seçmede kullandıkları ölçütleri ve yöntemleri değerlendirmeyi amaçlamaktadır. Özgün çokanlamlı kaynak metin sözcüğünün dilbilimsel-kültürel bağlamı incelenecek ve hedef metindeki yakın-eşanlamlılar ile karşılaştırılacaktır. Bu çalışma, eşanlamlı sözcüklerin genellikle kaynak metinde çokanlamlı sözcüklerin çağrıştırdığı anlamları ifade etmek üzere kullanıldı ̆̆ı ve hedef dildeki alıcı üzerinde özgün metnin etkisinin aynısının oluşturulmasına çalışıldığı dini metinlerin çevirisinde, önceliğin işlevsel düşünsel eşdeğerlik yerine biçimsel eşdeğerliğe verildiğini ileri sürmektedir.

Anahtar sözcükler: Çeviri, çokanlamlı sözcükler, eşanlamlı sözcükler, yineleme

This work was supported by Kuwait University Research Grant No. AE01/11

** Prof., Kuwait University, Faculty of Arts, English Department, jamalqinai@ hotmail.com

(C) 2012, Hacettepe University Faculty of Letters, All Rights Reserved 


\begin{abstract}
The question of using synonyms in translating the Quran is a thorny issue that led to both different interpretations and different translations of the holy text. No matter how accurate or professional a translator attempts to be, Quranic translation has always been fraught with inaccuracies and the skewing of sensitive theological, cultural and historical connotations owing to the peculiar mechanism of stress, semantico-syntactic ambiguity, prosodic and acoustic features, the mesh of special rhetorical texture and culture-bound references. Consequently, in most of the English interpretations of the Quran, cases of non-equivalence and untranslatability will be more frequent with plenty of scope for ambiguities, obscurities and fuzzy boundaries. The trend has been to accept exegetical translation based on commentary and explanation of the Quranic discourse. Since there is no uniform book of exegesis, translations are considered to be glosses or approximates for non-Arabic speaking Muslims. This study is mainly concerned with assessing the criteria and strategies used by different Quran translators in selecting synonyms to render Quranic polysemous words. The linguistic- cultural context of the original polysemous source text (ST) word will be analyzed and compared with its target text (TT) near-synonyms. The study argues that in translating religious texts where synonyms are usually used to convey implicated meanings of ST polysemous words and where we seek to have the same effect on the Target Language receiver as that of the original, the use of functional ideational equivalence is given primacy over formal equivalence.
\end{abstract}

Keywords: interpretation, polysems, synonyms, recurrence.

\title{
Introduction
}

Translators of sensitive texts such as religious scripture operate in contexts which can foster ambiguity, contradiction and misunderstanding, all of which are resolvable only in relation to the context and background of each particular verse. The notion of impartiality and neutrality has long been a crucial ethical controversy. As early as the third century BC, the translation of the Torah was never considered satisfactory partly because there was no standard original manuscript and translators freely included paraphrases and exegetical material. Generally speaking, early scripture translations were not read as texts in their own right but rather as aids to comprehension. (Baker, 1998, pp. 269-70). This paper propounds an alternative view whereby instead of encouraging translators to remain invisible, it calls for the recognition of the crucial role of the translator's interactive involvement in selecting the appropriate exegetical interpretation. In case of the Quran, the translator will often be confronted with culture-bound expressions that lead to coherence shifts in the target text (TT) reader perception. The translator's task is to fill any cultural void that may impede the TT readers' interpretability of the TT. Consequently, many translators of the Quran resort to periphrases, intertextual insertions and lengthy introductions and footnotes in order to bridge cultural gaps and thereby reduce TT coherence shifts.

Most translations of the Quran are source language oriented; because of the sensitive nature of the Holy text, accommodating TT readers is not an option (Baker, 1998, p. 201). Therefore, translations of religious texts are characterized by formal overloading (Nida, 1981, p. 71), archaism and over adherence to SL lexical peculiarities such as repetition and synonymy. Such are the traits of the translations by Bell (1937), Pickthall (1969), 
Arberry (1980), Asad (1980) and Ali (1983) whose aim was to maintain the rhetorical strategies and mystical effects of the Holy Scripture. Communicative translations using contemporary 'simple' English were used in the translations by Akbar (1978), Irving (1985) and Turner (1998) with the aim of making the translations intelligible to the masses and the young generation.

No matter how accurate or professional a translator attempts to be, Quranic translation has always been fraught with inaccuracies and the skewing of sensitive theological, cultural and historical connotations owing to the peculiar mechanism of stress, semanticosyntactic ambiguity, prosodic and acoustic features, the mesh of special rhetorical texture and culture-bound references. In order to select the best synonym for a given context or verse a translator has to refer to major Quranic exegeses in order to understand the underlying implication of a word, conjunction or even particle. Consequently, different exegetical analyses have led to variations in the choice of 'synonymous' yet not exactly identical lexical items in the target language. In view of the culture-bound schemata of the Quran, covert translation variations (or errors) are only discernible when various translations are compared with the original and its exegeses.

The question of whether or not the Quran uses synonymy is a very thorny issue that invites both different interpretations and different translations of the holy text. By definition, synonymous words should be substitutable in the utterance without affecting their conceptual meaning (Lyons, 1968, p. 446). Yet, despite cases of overlap in their core meaning, linguistic semantics dictate that there should be no absolute synonymy among words for that will result in a breach of the economy of language. Larson (1984, p. 73, 57) notes that there are sets of words which are synonymous in their fuzzy core meaning even though each may contain subtle positive or negative overtones. One may be more formal and another less formal; one word may be appropriate in one situation and the other appropriate in a different situation. Accordingly, an exact translation is probably impossible for every rendition will omit some sense or express some other possibly unwanted sense. Faithful translation, therefore, requires a sophisticated corpus-based lexical choice that can determine which of the synonyms provided by one language for a word in another language is the closest or most appropriate in any particular situation (Edmonds and Hirst, 2002).

This will naturally entail that upon transferring synonyms in between different languages we should expect partial synonymy instead of exact equivalence. Even words that are assumed to be translation equivalents differ in the degree of their distance from or proximity to the stem meaning. In order to avoid obscure renditions translators may prefer to explicate by rendering one word of the source language by several words in the receptor language as a means of disambiguating source text (ST) meanings. In sensitive texts such as the Quran, translations represent "varying degrees of paraphrase" (Nida, 1997, p. 95). Coupled with exegetical inaccuracies of the contextual and connotative meanings, cases of non-equivalence and untranslatability will be more frequent. This is particularly true when we consider semantic and lexical gaps that may exist in the TL for the SL cultural and linguistic peculiarities, ethnic practices, historical references as well as the stylistic and figurative aspects. Therefore, it is not uncommon to find cases of class, unit and structure shifts to compensate for the TL's voids (Catford, 1965, pp. 76-79). 
Divergence in transposing the possible connotations and synonyms of source text (ST) words is a common feature of Quranic translations. Robinson (1996, p. 4) remarks that Quranic translations are sometimes inconsistent in rendering a given word in a variety of different ways that makes it difficult for the reader to appreciate the coherence of individual suras and that of the Quran as a whole. Such variations in translation reflect the different ways of understanding the Quran and its exegeses by different translators. Therefore, our study will assess the interpretations of five of the best known translations of the Quran in terms of their effective rendering of polysemy, synonymy and recurrence into the target language (TL). These translations were carried out by Ali (1983) Translation of the Meanings of the Glorious Quran, Pickthall (1969) The Meaning of the Holy Quran, Asad (1980) The Message of the Quran, Shakir. M (1999) The Holy Quran and Arberry, A. J. (1980) The Koran Interpreted.

The difficulties of translating the Quran spring not only from the variations in the connotations of the selected synonyms but rather from infringing upon the rapport between sound and meaning which is a hallmark feature of the holy text both at the micro and macro levels. Therefore, a pragmatic translation of the meanings of the Quran would give approximate linguistic and rhetorical patterns for communicative purposes without claiming to be a true translation of the underlying subtleties of the original. Unlike redundant synonyms and recurrences in political texts, synonymous expressions in the Quran are used to convey certain implicated meanings which can only be rendered efficiently if the translator resorts to communicative functional equivalence. This is why Quranic 'translations' are often annexed with footnotes and marginal explanations to disambiguate the original meaning and supplement the translation with other possible interpretations.

This study is mainly concerned with how different translators dealt with Quranic words that seem to represent a case of synonymy. The study investigates the strategies used by different Quran translators in translating these words in selected verses, and analyzes the contexts where each pair occurs with a view to evaluating these translations. The linguistic- cultural context of the original synonyms will be analyzed whereby selected parallel translations of pairs of near-synonyms in the Quran are compared.

\section{Functional Recurrence}

Recurrence is a form of lexical cohesion achieved through the reiteration of a lexical item by way of using complete or partial recurrence, synonyms, near-synonyms, superodinates or collocations (Halliday, 1985, p. 310; Halliday \& Hasan, 1976, p. 278). Arabic uses recurrence as one of the most important devices of textual cohesion and rhetoric while English avoids repetition by using substitution, ellipsis or references (Aziz, 1998, p. 107). Despite the presence of cases of tautology and prolixity in Arabic poetry and literature, not all instances of recurrence are semantically redundant in the TT. In the translation of Holy Books and religious texts where translators should preserve the same functions and effects of the Holy Scripture, a lexical item repeated in the same context must be correspondingly repeated in the TT unless the original is poorly or loosely written (Newmark, 1981, p. 147). 
Deliberate motivated recurrence of a word in the same text with certain functions contributes to the efficiency of a text (de Beaugrande and Dressler, 1981, p. 134- 135). This study is mainly concerned with motivated 'informative' recurrence in the Quran that serves a specific function such as establishing a pervasive motif, emphasizing a certain concept (e.g. praise, guidance, warning, intimidation) or explicating an ambiguous context. One key method of deciphering the function of a recurrent phrase or lexical item is to look for polysemous words that may be repeated with variant nuances in each case. When no compatible polysemous nuances exist in English the use of recurrence in the TT may lead to a monotonous literal repetition that loses the impressive style of the Quran. In such cases, other translation strategies, such as using footnotes, paraphrases, substitution, translation couplets may be introduced (Hannouna, 2010, p. 109). Sometimes, translators will resort to the use of synonyms to avoid repetition, clarify the meaning of another lexical item or provide additional comments about the topic.

The analyses of recurrence cases in the present study indicate that the translations of the Quran by Ali, Asad and Irving show less repetition and more annotation. They focus on reflecting the function of repetition by using more varieties of words and meanings and giving primacy to the informative over the aesthetic aspect of the holy text. In comparison, Pickthall's, Arberry's and Shakir's are more literal as they attempt to be more economical by preserving the same forms and wordings of the ST. Their translations include a reproduction of the ST complete and partial recurrences which at times sound semantically redundant and less informative than the ST owing to the incompatibility between the ST and the TT in the nuances of recurrent polysemous words.

Functional recurrence occurs in surat al-Waaqi'ah (Q 56, 10):

و السابقون السابقون أولئك المقربون.

Wa-l-saabiqoon al-saabiqoon 'ulaa'ika l-muqarraboon.

According to the Quran exegesis by al-Tabari (Tafseer al-Tabari, 2000), the foremost in doing good (early Muslims i.e the Muhajireen 'migrants') are the foremost in their reward in the hereafter. On the other hand, Ibn Katheer (1993) states that alsaabiqoon are the prophets, martyrs and companions of the prophets although both include other categories such as those who race to the mosque for prayer, the first in doing good deeds and the most fearing of God. Ibn Katheer draws an analogy with verse 21 in surat al-Hadeed wherein the verb سابقو saabiqoo 'race, be foremost' is addressed to all Muslims:

سابقو ا إلى مغفرة من ربكم وجنة عرضها كعرض السماء و الآرض.

saabiqoo ilaa maghfiratin min rabbikum wa-jannatin 'arduhaa ka'ardi l-samaa'i wa-lard

Be ye foremost (in seeking) forgiveness from your Lord, and a Garden (of Bliss), the width whereof is as the width of heaven and earth (Ali, 1983, p. 1504)

Yet, three of the five interpretations of the Quran render the recurrence literally as if it were redundant.

- Pickthall: "And the foremost in the race, the foremost in the race."

- Shakir: "And the foremost are the foremost." 
- Arberry: "And the Outstrippers: the Outstrippers."

Only Asad and Ali provide lexical insertions to explain the reference to the exegesis:

- Asad: "But the foremost shall be [they who in life were] the foremost [in faith and good works]"

- Ali: "And those Foremost (in Faith) will be Foremost (in the Hereafter)."

In the following example, functional recurrence is used in the context of emphasis, intimidation and warning of the situation on the Day of Reckoning (Hannouna, 2010, p. 92).

كلا إذا دكت الأرض دكا دكا (al-Fajr, Q 89, 21)

Kallaa idhaa dukkat al-ardu dakkan dakkaa

"When the earth is pounded repeatedly and crushed (into pieces)"

Far from being pleonastic, the repetition of the word دكا dakkan is first done as a case of partial recurrence in relation to the verb دكت dukkat. Thus the first occurrence of دكا after the verb دكت dukkat constitutes a grammatical case of cognate accusative which is rendered in English by an adjectival or adverbial intensifier. Therefore, the mere repetition of the word in the TT renders it void of its grammatical and semantic function as we find in the translation by Asad and Pickthall:

- Asad: "Nay, but [how will you fare on Judgment Day] when the earth is crushed with crushing upon crushing."

- Pickthall: "Nay, but when the earth is ground to atoms, grinding, grinding."

However, Shakir, Ali, Arberry and Irving use adverbial intensifiers and/or other synonyms in order to preserve the grammatical and semantic function of the cognate accusative and reproduce the same degree of effectiveness of the SL text.

- Shakir: "Nay! When the earth is made to crumble to pieces."

- Ali: "Nay! When the earth is pounded to powder."

- Arberry: "No indeed! When the earth is ground to powder."

- Irving: "Indeed when the earth has been completely flattened out."

The verse also includes a complete recurrence in دكا دكا dakkan dakkan (literally, "a bang after a bang") denoting that the earth will be pounded repeatedly, forcefully and may be for quite a long time until it is ground to powder. Indeed the onomatopoeic segmental sounds دكا دكا dakkan dakkan emulate the action of constant and loud banging which emphasizes the emphatic function of 'warning' and 'threatening' regarding the woes on the Day of Reckoning. In order to preserve the 'aesthetic' function along with the emphatic one we may suggest a combination of recurrence and the insertion of an intensifier:

Indeed! When the earth is repeatedly pounded and pounded until it is completely flattened out.

Further, the aesthetic parallelism and the rhyming repetition of دكا دكا dakkan dakkan and صفا صفا saffan saffan [rank on rank] accentuate the semantic contrast in the verse; thus after anarchy there comes order. 
In surat al-Mursalaat (Q 77, 1-5)

و المرسلات عرفا ، فالعاصفات عصفا ، والناشر ات نشر ا .

Wa l-mursalati 'urfan. Fal'asifati 'asfan. Walnashirati nashran. Falfariqati farqan.

- Ali: "By the Winds sent forth one after another (to man's profit) which then blow violently in tempestuous gusts, and scatter (things) far and wide, then separate them, one from another."

- Irving: "By the [winds] sent forth for a purpose and gales that rage on and on, scattering things around; then dividing them all up."

The ST employs the cognate accusative as well as partial and parallel recurrence in order to perform an emphatic and informative function in the context of threatening and warning of the Resurrection. Hannouna (102) considers the instances of partial recurrence in the above verse as rhetorical devices in the ST. If translated literally, she remarks, they become irritating and ineffective in English since they furnish more information than is required and, therefore, can be considered as a semantic redundancy. As in other verses, the cognate accusative can be rendered communicatively in the TT by both recurrence and the insertion of an intensifier. Consequently, it is an effective rhetorical and semantic device in Arabic that cannot be labeled as redundant. In the following translation we attempted to integrate some intensifiers into Ali's translation in order to compensate for the missing recurrent words in the TT.

"By the benevolent winds, which are sent forth one after another

And by the tempestuous winds that blow violently

By the winds that scatter things (clouds and pollen) far and wide

Then distinctly separate them, one from another."

\section{Ambiguity, Polysemy and Synonymy}

One of the main obstacles to accurate translation is ambiguity resulting from puns of SL homonyms which are of the same form but of different meaning or polysemous words that refer to a number of concepts in a context-free environment. In non-sensitive texts the TL synonymous equivalents may be substituted for each other without a drastic change of the factual conditions or the core meaning of the overall text. In fact, many Arabic literary works, sermons and orations are reputed for their overuse of strings of synonyms and hendiadys for the purpose of stressing the emotive aspect of the text or explicating its meaning. Translating such parallel couplings in the TL may look redundant as English does not tolerate the proliferation of synonyms.

Since absolute synonymous equivalents in translation are rare, partial synonyms are often substituted depending on their denotative and connotative meaning (Bussmann et al., 1998, p. 471). At the lexical level, the semantic gradation of synonyms reflects fine distinctions in their componential analysis, nuances, tones, attitudes, etc. The first synonym may not replace the second in the same context; sometimes nuances and attributes are used instead of the core word as in the attributes أدهم adham 'black horse' and جواد jawaad 'fast horse' which are hyponym s of the generic word حصان ' hisaan 
'horse' (Shehab, 2009, p. 87). Consequently, TL equivalent(s) may not denote exactly the same range of concepts for a given ST polysemous word. The problem is aggravated in the presence of historical references and cultural nuances as in the case of sacred texts. Therefore, there are translation alternatives that different translators may choose from according to their own interpretation of context particularly when the cues from the adjacent words are not decisive enough.

The word و إنـا لحب الخير لثديد al-khayr in the verse الخير abnahu li-hubbi l-khayri la-shadeed is a good example of divergence due to ambiguity in translation (Abdul-Raof, 2001, p. 34). Thus while Al-Qurtubi (1997, vol 20, p. 151) gives it the correct equivalent of 'wealth', Turner (1998, p. 370) provides a wrong translation as 'fast horses' whereas Arberry (1980, vol 2, p. 349) gives an inappropriate meaning of 'good things'. As for المتقين al-muttaqeen (Q 2, 2), it is rendered by Bell (1937, vol 1, p. 3) as 'those who act piously', Pickthall (1969, p. 24) 'those who ward off (evil)' Asad (1980, p.3) 'the Godconscious', Arberry (1980, vol 1, p. 30) 'god-fearing' and by al-Hilali and Khan (1983, p. 3 ) as "those who are al-muttaqoon' and it is explicated in a long paraphrase as "the pious and righteous persons who fear Allah much (abstain from all kinds of sins and evil deeds which He has forbidden) and love Allah much (perform all kinds of good deeds which He has ordained."

Abdul-Raof's (2004) survey of existing English versions of the Quran shows that the most a translator aims at is the communication of the message without considering the idiosyncrasies and prototypical features of the Quranic discourse. The versatility of Quranic lexemes and styles were not captured in most of the English versions of the Quran. For example, the fine subtleties of Quranic synonymous nuances are best expressed in the words سنة sana and عام 'aam which are both rendered as 'year' despite the fact that سنة sana is often associated with suffering, perseverance and agony while 'aam is occasionally used in the context of benevolence and good deeds. This lexical void in English results in under-translating the implications of the Arabic verse. For example, سنة sana is used with a negative sense to imply a long life of misery and affliction that will not benefit those who cling to life.

$$
\text { يود أحدهم لو يعمر ألف سنة وما هو بمزحزحه من العذاب. }
$$

Yawaddu ahaduhum law yu 'ammaru alfa sanatin wamaa huwa bi-muzahzihihi mina l-'adhaabi (Q 2, 9).

-Asad: every one of them would love to live a thousand years, although the grant of long life could not save him from suffering [in the hereafter].

-Ali: Each one of them wishes He could be given a life of a thousand years: But the grant of such life will not save him from (due) punishment.

A similar sense of loss and agony is expressed by the word sana when the children of Israel were afflicted with forty years in the wilderness.

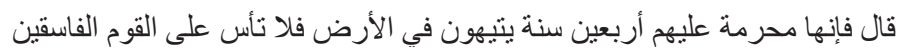

Qaala fa-'innahaa muharramatun 'alayhim arba'eena sanatan yateehoona fee-l'ardi falaa ta'sa 'ala l-qawmi l-faasiqeen (Q 5, 26). 
- Asad: Answered He: Then, verily, this [land] shall be forbidden to them for forty years, while they wander on earth, bewildered, to and fro; and sorrow thou not over these iniquitous folk.

-Ali: Allah said: Therefore will the land be out of their reach for forty years: In distraction will they wander through the land: But sorrow thou not over these rebellious people.

Yet, the word عام 'aam is associated with a promising year of bounteous harvest.

ثم يأتي من بعد ذلك عام فيه يغاث الناس وفيه يعصرون.

Thumma ya'tee min ba'di dhaalika 'aamun feehi yughaathu l-naasu wa-feehi ya'siroon (Q 12, 49)

-Asad: And after that there will come a year in which the people will be delivered from all distress, and in which they will press [oil and wine as before].

-Ali: Then will come after that (period) a year in which the people will have abundant water, and in which they will press (wine and oil).

In a similar vein, the Arabic words ياس ya's and قنوط qunoot are partial synonyms since they differ in degree. يأس ya's implies the ordinary state of being hopeless or desperate while قنو qunoot is a more intense level of losing hope and being 'truly desperate, utterly wretched, totally despondent' (al-Mu'jam al-Waseet, 2004; Ibn-Manzour, 1970; Shehab, 2009, p. 897). Yet, the English interpretations of the Quran do not reflect this distinction; both words are rendered as either 'become hopeless' or 'desperate' interchangeably with no special equivalent for ari qunoot. It would have been more accurate to use a lesser degree of intensity for يأس ya's such as 'frustrated', 'discouraged', 'dispirited', 'depressed' or 'disheartened' while preserving 'despair' for قنوط qunoot. Otherwise, an intensifier should precede the word 'despair' when used for قنوط qunoot. Thus in surat Yusuf (Q 12), when Jacob encourages his sons to endure and be patient while searching for Joseph (al-Tabari, 2000, vol 16, p. 233), he admonishes them not be discouraged or frustrated for God's mercy is imminent, just a stone's throw away. As a prophet, with visionary perception, he is certain that God will never abandon them to despair. Yet, four translations use 'despair' while the fifth uses 'lose hope'.

$$
\text { و لا تيأسوا من روح الله إنه لا ييأسَ من روح الله إلا القَُّمُ الكافرون. }
$$

walaa tay'asoo min rawhi Allaahi innahu laa yay'asu min rawhi Allaahi illa al-qawmu al-kafiroon. (Yusuf, Q 12, 87)

- Asad: "Do not lose hope of God's life-giving mercy: verily, none but people who deny the truth can ever lose hope of God's life-giving mercy."

- Pickthall: "Despair not of the Spirit of Allah. Lo! none despaireth of the Spirit of Allah save disbelieving folk."

- Shakir: "Despair not of Allah's mercy; surely none despairs of Allah's mercy except the unbelieving people."

- Ali: "Do not despair of God's mercy; none but those who deny the truth despair of God's mercy." 
- Arberry: "Do not despair of God's comfort; of God's comfort no man despairs, excepting the people of the unbelievers."

On the other hand, in verse 53 of surat az-Zummar God addresses those who have transgressed against themselves to believe in His mercy and not to be despondent by reaching the stage of utter despair. In this context, reaching the stage of 'utter despair' corresponds with reaching the extreme point of being 'extravagant' with oneself.

$$
\text { قل باعبادي الذين أسرفوا علَى أَنفهم لا تقنطو ا من رحمة الله. }
$$

Qul ya-'ibadiya lladheena asrafoo 'alaa anfusihim laa taqnatoo min rahmati Allaahi. (al-Zummar Q 39, 53)

- Asad: "SAY: [Thus speaks God:] 'O you servants of Mine who have transgressed against your own selves! Despair not of God's mercy."

- Pickthall: "Say: O My slaves who have been prodigal to their own hurt! Despair not of the mercy of Allah."

- Shakir: "Say: O my servants! who have acted extravagantly against their own souls, do not despair of the mercy of Allah."

- Ali: "Say: O my Servants who have transgressed against their souls! Despair not of the Mercy of Allah."

- Arberry: "Say: O my people who have been prodigal against yourselves, do not despair of God's mercy."

Pickthall, Ali and Shakir render the word يوسوس yawaswis in the verse صدور النّاس من شر الوسواس الخنّاس الَّي يوسوس في min sharri al-waswaas al-khannaas alladhee yawaswisu fee sudoori l-naas (Q 114,4) as "whisper" which back-translates into

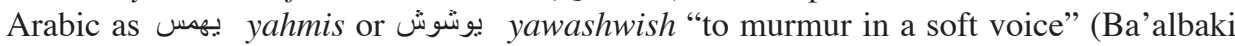
2000). The connotations of يوسوس yawaswis extend to include the devil's secretive incitements, the inner self as it provokes man to commit sin and the iconic jingle of rattling jewelry. Since there is no exact one-to-one equivalent in the English lexicon, the equivalent "to whisper" lacks the essential connotations of the Arabic verb that include evil and incitement and the aesthetic 'hissing' sound of the ST that imply plotting in secrecy. Further, يوسوس yawaswis may indicate mute incitements of the inner self. Contrary to the all-negative sense of the Arabic word يوسوس yawaswis that collocates with the devil, the English verb 'to whisper' may include a positive sense. In addition to "speaking quietly and privately, as by way of gossip, slander, or intrigue" Collins Dictionary lists other definitions that associate with the rustle of leaves (Collins English Dictionary, 2011). In order to restrict the translation to the negative connotations of 'whisper', the three most popular translators of the Quran insert lexical modifiers:

- Ali: "From the mischief of the Whisperer (of Evil), who withdraws (after his whisper)."

- Pickthall: "From the evil of the sneaking whisperer."

- Shakir: "From the evil of the whisperings of the slinking (Shaitan)."

Polysemous words may create ambiguous word puns if used in successive recurrence in the same verse. Thus, in surat Al-Roum, verse 55 
Wa-yawma taqoomu l-ssaa'a yuqsimu al-mujrimoona maa labithoo ghayra saa' $a$, the translators attempted to recreate the pun in the target renderings by repeating the same word سـاعة while capitalizing the initial H in the first 'Hour' which refers to 'Judgement Day'. This verifies the knowledge of the translators of the wordplay in the Quran (Dastjerdi, 2011, p. 139).

- Asad: "And when the Last Hour dawns, those who had been lost in sin will swear that they had not tarried [on earth] longer than an hour."

- Pickthall: "And on the day when the Hour riseth the guilty will vow that they did tarry but an hour."

- Shakir: "And at the time when the hour shall come, the guilty shall swear (that) they did not tarry but an hour."

- Ali: "On the Day that the Hour (of Reckoning) will be established, the transgressors will swear that they tarried not but an hour."

- Arberry: "Upon the day when the Hour is come, the sinners shall swear they have not tarried above an hour."

\section{Under-translation of Polysems}

The referential versatility of Quranic lexemes undergoes semantic reduction when Quranic translators render a polysem as a monosem. For example, the word al-falaq Q 113,1) is translated as "daybreak" by Pickthall and Arberry, "dawn” by Asad, Shakir and Ali whereas it can be generally used to refer to the process of splitting as in cell multiplication including seeds, molecules and biological entities (Abdul-Raof, 2004). Likewise, the primary meaning of the word خاشَع khaashi“ is "to be humble, submissive, pious and devout [as in prayer]" (Ba'albaki, al-Mawrid Arabic English Dictionary), while in the exegeses it is assigned a secondary sense of 'being desolate, barren' (Ibn Khatheer, 1993, p. 182).

This is attested to in verses 1-2 of al-Mu'minuun (The Believers Q 23):

$$
\text { قد أفلح المؤمنون الذين هم في صلاتهم خاثعون. }
$$

Qad aflaha al-mu'minuun allatheen hum fee salaatihim khaashi 'oon

Asad: "Truly, to a happy state shall attain the believers those who humble themselves in their prayer."

The same word is used both literally and metaphorically in verse 39 of Fussilat where a desolate earth is compared to a human being in a state of submissive worship praying to God to elevate a calamity.

$$
\text { ومن أياته أنكّك تزى الأرض خاشعة فَّاذا أنزلنا عليها الماء اهنزّت ورُبت. }
$$

Wa-min aayaatihi annaka tara l-ardha khaashi'atan fa'idhaa 'anzalnaa 'alyhaa almaa'a ihtazzat wa-rabat (Fussilat Q 41, 39)

With the exception of Pickthall, the other most popular interpretations of the Quran fail to render the common meaning of khaashi 'atan as 'humble' or 'submissive'.

- Asad: "For among His signs is this: thou seest the earth lying desolate - and lo! When We send down water upon it, it stirs and swells [with life]!" 
- Pickthall: "And of His portents (is this): that thou seest the earth lowly, but when We send down water thereon it thrilleth and groweth."

- Shakir:: "And among His signs is this, that you see the earth still, but when We send down on it the water, it stirs and swells."

- Yusuf Ali:: "And among His Signs in this: thou seest the earth barren and desolate; but when We send down rain to it, it is stirred to life and yields increase."

- Irving: "Among his signs, you see how desolate the earth is; yet whenever we send water down upon it, it stirs and sprouts."

The earth, heavens, animate and inanimate objects (birds, trees, mountains, thunder) are treated in the Quran as living beings that pray and understand when spoken to by God and his messengers. Instances of personification of inanimate objects are present in several verses. Thus in al-Dukhaan (Q 44,29) the sky is assigned a human trait of weeping: فما بكت عليهم السّماء والأرض وما كانو ا منظرين Fama bakat 'alayhimu l-samaá wal-ardu wamaa kanoo mundhareen "and neither sky nor earth shed tears over them, nor were they allowed a respite" (Asad). Likewise in al-Hashr (Q 59, 21) The Almighty

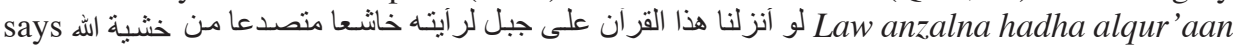
'alaa jabalin la-ra'aytahu khashi'an mutasaddi'an min khashyati Allaah "Had We sent down this Quran on a mountain, verily, thou wouldst have seen it humble itself and cleave asunder for fear of Allah" (Ali).

It is narrated that when prophet Mohammad (PBUH) was ascending the pulpit, a nearby tree trunk started moaning and groaning upon hearing the words of revelation. To exclude TL synonyms other than 'desolate' and 'barren' for the word khaashi'atan constitutes a case of divergence from the ST by way of under-translation. Johnstone (1991, p. 177) propounds that instead of the logical structure of proof which Westerners see behind the words, Arabic uses repetition as a means of assertion and persuasion. Ali, however, refutes Johnstone's argument by stressing that far from being a mere rhetorical device, the wording of the Quran is deliberate; every word serves a purpose; and deformation of the text's original meaning can occur if the repetition is not adequately catered for in the translation (Ali, 2006, p. 26). Yet, Ali erroneously cites an example of polysemy in surat Yusuf as a case of repetition. In the verse (Q 12, 4):

$$
\text { إذ قال يوسف لأبيه يا أبت إني رأيت أحد عشر كو كبا و الثمس و القمر رأيتهم لي ساجدين. }
$$

'idh qaala yoosufu li-abeehi innee ra'aytu ahada 'ashara kawkaban wa-l-shams wal-qamar ra'aytuhum lee saajideen.

O my father! Lo! I saw in a dream eleven planets and the sun and the moon, I saw them prostrating themselves unto me.

Ali finds that the repetition of رأيت ra'aytu 'I saw' indicates that there was not the least doubt in Joseph's mind that what he saw was real and not just a normal dream (Ali, 1991, p. 27). The word رؤية رأى Arabic may serve as the triliteral verbal stem for both ru'yah 'seeing' by means of physical eyesight" and رؤيا ru'yaa "conceiving a vision of future events while asleep" (al-Munjid, 1986, p. 243). This is attested to by Joseph's father's answer not to tell his brothers about his "visionary" dream رؤياك ru'yaaka $(\mathrm{Q}$ $12,5)$. Thus a visionary dream is more significant than a casual dream or as it is termed 
adghathu ahlaam “A confused medley of meaningless dreams and nightmares of no particular significance according to surat Yousef (Q 12, 44)

$$
\text { قالو ا أضغاث أحلام وما نحن بتأويل الأحلام بعالمين }
$$

qaaloo adghaathu ahlaam wa-maa nahnu bi-ta'weeli l-ahlaami bi-'aalimeen.

They said: A confused medley of dreams: and we are not skilled in the interpretation of dreams."

In this verse, the repetition of the verb رأيت ra'aytu is not as Johnstone (1991, p. 29) claims simply a rhetorical device merely intended to persuade the readers by creating a logical link between the anterior and posterior parts of the verse, but rather it emphasizes that what Joseph saw was more like a dream come true. The repetitive nature of his language is precursive to an actual event predestined by God's will as testimony to Joseph's prophethood (Ali, 2006, p. 27).

Yet, the four most popular translations of the Quran fall short from realizing the polysemous nature of رأيت ra'aytu. Shakir and Ali simply repeat the verb 'I saw' while Asad and Pickthall insert the word dream.

- Asad: "LO! Thus spoke Joseph unto his father: "O my father! Behold, I saw [in a dream] eleven stars, as well as the sun and the moon: I saw them prostrate themselves before me!"

- Pickthall: "When Joseph said unto his father: O my father! Lo! I saw in a dream eleven planets and the sun and the moon, I saw them prostrating themselves unto me."

- Shakir: "When Yusuf said to his father: O my father! Surely I saw eleven stars and the sun and the moon-- I saw them making obeisance to me."

- Yousef Ali: "Behold! Joseph said to his father: O my father! I did see eleven stars and the sun and the moon: I saw them prostrate themselves to me!"

Finally, the word إقترف: iqtarafa is often used in the context of committing a sin or perpetrating a criminal act. Nevertheless, in surat al-Tawbah it is used with money to imply that it is a base earthly gain that should not deviate man from the true love of God.

$$
\begin{aligned}
& \text { قل إن كان آباؤكم و أبناؤكم و اخو انكم وأزو اجكم و عشير تكم و أمو ال اقتر فتمو ها } \\
& \text { وتجارة تخشون كسادها ومساكن ترضونها أحب إليكم من الله ... }
\end{aligned}
$$

Qul in kaana aabaa 'ukum wa-abnaa 'ukum wa-ikhwaanukum wa-azwaajukum wa'asheeratukum wa-amwaalun iqtaraftumooha wa-tijaaratun takhshawna kasaadaha wamasaakinu tardawnahaa ahabba ilaykum mina Allaahi. (Q 9, 24).

Almost all the translations given by the five well known interpreters erroneously render the word iqtarafa by a more euphemistic equivalent such as 'acquire' or 'gain' thus glossing over the negative nuance of the ST word.

-Asad: Say: If your fathers and your sons and your brothers and your spouses and your clan, and the worldly goods which you have acquired, and the commerce whereof you fear a decline, and the dwellings in which you take pleasure - [if all these] are dearer to you than God. 
-Ali: Say: If it be that your fathers, your sons, your brothers, your mates, or your kindred; the wealth that ye have gained; the commerce in which ye fear a decline: or the dwellings in which ye delight - are dearer to you than Allah.

-Pickthall: Say: If your fathers, and your sons, and your brethren, and your wives, and your tribe, and the wealth ye have acquired, and merchandise for which ye fear that there will be no sale, and dwellings ye desire are dearer to you than Allah.

\section{Determining Polysemy by Means of Collocation}

Some cases of formal recurrence of polysemous words may be misleading to the translator if he ignores their subtle nuances and decides to repeat them in the TT, unless the context and other adjacent collocates dictate a different rendering. A case in point is surat al-Rahmaan (Q 55) wherein the polysemous word الميزان al-meezaan occurs in three consecutive verses with synonymous variations in meaning. Thus, in verse 7 it stands for both the actual balance in creating the skies and all creation with delicate measurement and the balance of justice in reward and punishment, conviction and vindication.

$$
\text { و السماء رفعها ووضع الميز ان، آلا تطغو ا في الميزان، و أقيموا الوزن بالقسط و لا تخسروا الميزان. }
$$

Wa-l-samaa'a rafa'ahaa wa-wada'a al-meezaan allaa tatghoo fee al-meezaan waaqeemoo al-wazna bi-l-qisti walaa tukhsiroo al-meezaan.

The collocation of the word المغنوان tatghoo 'transgress' and-meezaan 'balance, equity, justice' in verse 8 would narrow the choices for the translator in favour of 'equity' or 'justice' since, contrary to celestial justice, earthly tyrants may do injustice by encroaching on and contravening others' rights. However, in verse 9 the association between the collocates قسط qist 'fair or exact measurement' and تخسرو 'depreciate, reduce/decrease in the scale as a measuring instrument, skimp the balance' would incline the translation towards the primary meaning of الميزان al-meezaan as the 'instrument' with which one weighs although the sense of establishing justice and equity cannot be excluded.

With the exception of Asad, the other four popular translators of the Quran tend to indiscriminately repeat the word 'balance' or 'measure' with little or no intertextual commentaries to help the reader understand the implications of the recurrence in light of the adjacent collocates.

- Asad: "And the skies has He raised high, and has devised [for all things] a measure, so that you [too, O men,] might never transgress the measure [of what is right]: weigh, therefore, [your deeds] with equity, and cut not the measure short!"

- Ali: "And the Firmament has He raised high, and He has set up the Balance (of Justice), In order that ye may not transgress (due) balance. So establish weight with justice and fall not short in the balance."

- Pickthall: "And the sky He hath uplifted; and He hath set the measure, that ye exceed not the measure, But observe the measure strictly, nor fall short thereof."

- Shakir: "And the heaven, He raised it high, and He made the balance, That you may not be inordinate in respect of the measure. And keep up the balance with equity and do not make the measure deficient." 
- Arberry: "And heaven -- He raised it up, and set the Balance. Transgress not in the Balance, and weigh with justice, and skimp not in the Balance."

On the other hand, some words may be erroneously rendered as synonymous when considered in isolation. Out of context, the pair الريح al-riyaah may be mistaken for absolute synonyms since the latter is the plural form of the former (Shehab, 2009, pp. 880-881). Yet in the following verse:

و أما عاد فأهلكو ا بريح صرصر عاتية.

Wa-amma 'aadun fa-'uhlikoo bi-reehin sarsarin 'aatiya (al-Haaqqah, Q 69, 6)

The presence of the collocate عاتية 'aatiyah "tempestuous, fierce" narrows the sense down to that of an unfavourable wind.

- Asad: "And as for the 'Ad - they were destroyed by a storm wind furiously raging."

- Ali: "And the "Ad, they were destroyed by a furious Wind, exceedingly violent."

- Pickthall: "And as for A'ad, they were destroyed by a fierce roaring wind."

- Shakir: "And as to Ad, they were destroyed by a roaring, violent blast."

- Arberry: "And as for Ad, they were destroyed by a wind clamorous."

As the above translations indicate الريح al-reeh is used in the Quran to implicate torment and destruction and hence can be translated ideationally as "fierce, violent wind, raging storm" and functionally as "gale" (Shehab, 2009, p. 887). Yet, the word الرياح alriyaah in verse 48 of surat al-Roum carries a different nuance as "blessing winds".

الله الذي يرسل الرياح فتثير سحابا فيبسطه في السماء كيف يشاء و يجعله كسفا فترى الودق يخرج من خلاله.

Allahu alladhee yursilu l-riyaaha fatutheeru sahaaban fa-yabsutuhu fee l-samaa'i kayfa yashaa'u wa-yaj'aluhu kisafan fatara l-wadqa yakhruju min khilaalihi.

- Asad: "It is God who sends forth the winds [of hope], so that they raise a cloud whereupon He spreads it over the skies as He wills, and causes it to break up so that thou seest rain issue from within it."

- Ali: "It is Allah Who sends the Winds, and they raise the Clouds: then does He spread them in the sky as He wills, and break them into fragments, until thou seest raindrops issue from the midst thereof."

- Pickthall: "Allah is He Who sendeth the winds so that they raise clouds, and spreadeth them along the sky as pleaseth Him, and causeth them to break and thou seest the rain downpouring from within them."

- Shakir: "Allah is He Who sends forth the winds so they raise a cloud, then He spreads it forth in the sky as He pleases, and He breaks it up so that you see the rain coming forth from inside it."

- Arberry: "God is He that looses the winds, that stir up clouds; and He spreads them in heaven how He will, and shatters them; then thou seest the rain issuing out of the midst of them."

With the exception of Asad's ideational translation where the word 'winds' is postmodified by 'of hope' none of the other translators uses any adjective to implicate that 
unlike الرياح al-riyaah these are benevolent winds of blessings and bounties. The textual clue is offered in the adjacent word 'rain' and the word 'rejoice' in the following verse line. Even though the word 'winds' is a reasonable equivalent to الرياح' al-riyaah as both words share the same sense of moving or stirring up the clouds and sending down rain, yet, since we are dealing with a Quranic text where slight differences of lexical items do count, it could be more faithful if we reflect the difference based on adjacent words in the immediate context (Shehab, 2009, pp. 880-881).

Similarly, Farghal (2010, p. 173) notes that Arberry undertranslates the Quranic euphemistic term ' $u d d a h$ 'the legally prescribed period of three months before a divorced woman can remarry, in order to rule out pregnancy' as simply 'period' which can be easily confused with 'menstrual period'.

$$
\text { يأيها النبي إذا طلقتم النساء فطلقو هن لعدتهن واحصوا العدة واتقو الله ربكم. }
$$

Ya-'ayyuha l-nabiyyu idhaa țallaqtumu l-nisaa'a fa-talliqoohunna li-'iddatihinna wa-ahsuu l-'iddata wa-ttaqoo Allaaha rabbakum.

-Arberry: O Prophet [Mohammad] when you divorce women, divorce them when they have reached their period. Count the period, and fear your lord.

The collocations of divorce help the ST reader determine the sense of 'period' as that of conception rather than the monthly menstrual period. The translator could have mediated by explicating the equivalent in favour of the TT recipient.

\section{Determining Polysemy and Synonymy by Morphological Form and Textual Adjacency}

Arabic employs subtle morphological distinctions in the patterns of word formation; a single diacritic (short vowel) may lead to significant semantic differences as illustrated in the following example.

In surat al-Kafiroon (Q 109), the word عابدون 'aabidun is repeated twice in successive verses $(3,5)$.

Qul yaa-'ayyuha l-kaafiroon

"Say: O disbelievers!"

la a'budu ma-ta'budoon

"I do not worship that which you worship."

و ولا أنتم عابدونَ ما أعبد walaa antum 'aabidoon maa-a'bud

"And neither do you worship that which I worship."

walaa anaa 'aabidun maa 'abadtum

"And I will not worship that which you have [ever] worshipped."

walaa antum 'aabidoon maa a'bud

"And neither will you [ever] worship that which I worship." 
Although verses 3 and 5 have exactly identical lexes and syntax yet they have different interpretations in respect of tense and aspect. The present participle form ( $2^{\text {rd }}$ person plural (aabidoon stands for the present time "nor do you worship what I worship" since the coordinate conjunction $و$ is preceded by the present verb form تعبدون ta'bodoon "you worship (now)". Yet, in verse 5 the same word عابدون "aabidoon is rendered in the future tense as "you will worship" in line with the preceding present participle form ( $11^{\text {st }}$ person plural) عابد 'aabidun in verse 4.

The verb يحلف yahlif is used in the Holy Quran in the context of the hypocrites severing their oath whereas the verb أقسم uqsim is used in honest, sincere oaths. Since there is no correspondent verb other than 'swear' in English to relay this delicate difference between the two synonyms, we may resort to ideational equivalence such as "untruthfully swear" for يحلفون. yahlifoon and "truthfully swear" for يقسم yaqsim (Shehab, 2009, p. 881). Thus in surat al-A'raaf (Q 7, 21) وقاسـمها إني لكما لمن الناصحين wa-qaasamahumaa innee lakumaa lamin al-naasiheen "And he swore to them both, that he was their sincere adviser" the verb 'swear' is intended in the positive sense of 'taking a solemn oath'.

Nevertheless, the negative sense of 'dishonest, untruthful oath' in surat al-Tawbah $(\mathrm{Q} 9,56)$ is congruent with the repudiation in the latter part of the verse that the hypocrites do not belong to Muslims.

ويحلفون باله إنهم لمنكم وما هم منكم ولكنهم قوم يفرقون

wa-yahlifuun bi-llaahi innahum la-minkum wa-maa-hum minkum wa-laakinnahum qawmun yafraqoon

Yet, none of the five translations uses any qualifying modifiers such as 'dishonestly' or 'deceitfully' before the word 'swear' to reflect this implication.

- Asad: "And they swear by God that they do indeed belong to you -the while they do not belong to you, but are [only] people ridden by fear."

- Pickthall: "And they swear by Allah that they are in truth of you, when they are not of you, but they are folk who are afraid."

- Ali: "They swear by Allah that they are indeed of you; but they are not of you: yet they are afraid (to appear in their true colours)."

- Shakir: "And they swear by Allah that they are most surely of you, and they are not of you, but they are a people who are afraid (of you)."

- Arberry: "They swear by God that they belong with you, but they are not of you they are a people that are afraid."

The word ماء 'water' is frequently used in the Quran to refer exclusively to 'graceful, nourishing rain'

$$
\text { هو الذي أنزل من السماء ماء لكم منه شر اب ومنه شجر فيه تسيمون. }
$$

Huwa llathee anzala mina l-sama'i maa'an lakum minhu sharaabun waminhu shajarun feehi tuseemoon (Q 16, 10).

With the exception of Ali, the other four translators preferred to use 'water' rather than 'rain' in order to reflect the benign nature of this kind of rain in juxtaposition with 'destructive rainstorms'. 
- Asad: "It is He who sends down water from the skies; you drink thereof, and thereof [drink] the plants upon which you pasture your beasts."

- Pickthall: "He it is Who sendeth down water from the sky, whence ye have drink, and whence are trees on which ye send your beasts to pasture."

- Ali: "It is He who sends down rain from the sky: from it ye drink, and out of it (grows) the vegetation on which ye feed your cattle."

- Shakir: "He it is Who sends down water from the cloud for you; it gives drink, and by it (grow) the trees upon which you pasture."

- Arberry: "It is He who sends down to you out of heaven water of which you have to drink, and of which trees, for you to pasture your herds."

The word matar 'rain' in Arabic is sometimes used interchangeably with the synonym غيث ghayth. The latter, often alludes to relief and long-awaited rain after a draught as in the following verse of surat al-Shooraa (Q 42, 28)

$$
\text { وهو الذي ينزل الغيث من بعد ما قنطو اوينشر رحمنه وهو الولي الحميد. . }
$$

Wa-huwa lladhee yunazzilu l-ghaytha min ba'di maa-qanatoo wa-yanshuru rahmatahu wahuwa l-waliyyu l-hameed.

The peculiar sense of غيث ghayth as "relief" is implied in the adjacent words in the context (after they have despaired, unfolds his mercy, grace). The translations of this verse invariably render the word غيث ghayth as 'rain' albeit Pickthall adds a qualitative adjective 'saving'.

- Asad: "And it is He who sends down rain after [men] have lost all hope, and unfolds His grace..."

- Pickthall: "And He it is Who sendeth down the saving rain after they have despaired, and spreadeth out His mercy..."

- Ali: "He is the One that sends down rain (even) after (men) have given up all hope, and scatters His Mercy (far and wide)..."

- Shakir: "And He it is Who sends down the rain after they have despaired, and He unfolds His mercy..."

- Arberry: "And it is He who sends down the rain after they have despaired, and $\mathrm{He}$ unfolds His mercy..."

Although مطر matar is often used as the neutral superordinate or hypernym word, yet in the Quran it is also used in the context of a penalty imposed by God for wrongdoing (Shehab, 2009, 881-882) as in verse 58 of surat al-Naml (Q 27) where the rain is described as 'evil' and 'dreadful'.

$$
\text { و وأمطرنا عليهم مطر ا فساء مطر المنذرين 'alasa }
$$

Wa-amtarna 'alayhim mataran fasaa'a mataru l-munthareen

As with the synonym غيث ghayth, English translations use the same word 'rain' since there seems to be no other alternative but to modify it with adjectives or explicating phrases. 
- Asad: the while We rained a rain [of destruction] upon the others: and dire is such rain upon all who let themselves be warned [to no avail].

- Pickthall: "And We rained a rain upon them. Dreadful is the rain of those who have been warned."

- Ali: "And We rained down on them a shower (of brimstone): and evil was the shower on those who were admonished (but heeded not)!"

- Shakir: "And We rained on them a rain, and evil was the rain of those who had been warned."

- Arberry: "And We rained on them a rain; and evil indeed is the rain of them that are warned."

Other synonyms for مطر sayyib which is used in surat alBaqarah (Q 2, 19) with the sense of a violent and destructive rainstorm that frightens the disbelievers.

$$
\text { أو كصيب من السماء فيه ظلمات ور عد وبرق يجعلون أصابعهم في آذانهم من الصنو اعق حذر الموت. }
$$

Aw ka-sayyibin mina al-samaa'i feehi thulumaatun wa-ra 'dun wa-barqun yaj 'aloona asaabi'ahum fee aathaanihim mina al-sawaa 'iqi hathara al-mawti.

Yet, the renditions given by the five translators of the Quran fall short of finding an equivalent synonym in English and instead insert other lexical modifiers.

- Asad: "Or [the parable] of a violent cloudburst in the sky, with utter darkness..."

- Pickthall: "Or like a rainstorm from the sky, wherein is darkness..."

- Ali: "Or (another similitude) is that of a rain-laden cloud from the sky: In it are zones of darkness..."

- Shakir: "Or like abundant rain from the cloud in which is utter darkness..."

- Arberry: "Or as a cloudburst out of heaven in which is darkness..."

In all the above examples, the morphological form of the word, the adjacency of collocates and other modifiers (adjectives and explicating phrases) within the same context narrow down the nuances of polysemous words and help the translator in eliminating redundant synonyms.

\section{Conclusion}

This paper has focused on the issue of translating polysemous words and their recurrence in the Quran with different nuances in adjacent contexts. By analyzing the corpus of examples of the various English interpretations of the Quran we realized that some deviations and undertranslations are the result of insufficient reference to the exegeses of the Quran, lack of understanding of Arabic morphology and inability to decode the nuances of polysemous words. If translators choose to undertranslate by ignoring the nuances and connotations of polysemous and recurrent words, they would fail to accommodate all the meanings of the original; this is because synonyms, polysems and repeated words in the Quran serve a purpose. Instances of recurrence may either be repeated formally or erroneously interpreted as semantic redundancies in the TT. In order to maintain the informative and aesthetic functions of recurrent Quranic words 
and phrases, translators should attempt to reproduce them in approximate functional equivalents or compensate their deletion with lexical insertions, annotations or ideational equivalents.

It should be noted that, unlike English, Arabic uses extended cognitive synonyms and recurrences of polysemous words. When it comes to translating non-sensitive texts, some translators may not find the urgency to preserve the subtle differences which exist among such synonyms and recurrences. Yet, upon dealing with sensitive and religious texts, a translation solely based on the conceptual and denotative meaning of synonymous or polysemous words may be incongruent with their connotations and implications. So, in order to relay the exact implicated meaning of the ST, one may resort to ideational or annotated renditions wherein reference should be made to the exegeses, books of prophetic traditions and Arabic heritage dictionaries Thus, the text-type is paramount in deciding what translation equivalence translators should opt for.

The analyses of recurrence cases in the present study indicate that the translations of the Quran by Ali, Asad and Irving show less repetition and more annotation. They focus on reflecting the function of recurrence by using more varieties of words and meanings and giving primacy to the informative over the aesthetic aspect of the holy text. In comparison, Pickthall's, Arberry's and Shakir's are more literal as they attempt to be more economical by preserving the same forms and wordings of the ST. Their translations include a reproduction of the ST complete and partial recurrences which at times sound semantically redundant and less informative than the ST owing to the incompatibility between the ST and the TT in the nuances of recurrent polysemous words.

\section{References}

Abdul-Raof, H. (2001). Quran translation: Discourse, texture and exegesis. Surrey, UK: Curzon Press.

Abdul-Raof, H. (2004). The Quran: Limits of translatability. In Said Faiq (Ed.), Cultural Encounters in Translation from Arabic (pp. 91-106). Clevedon, Buffalo \& Toronto: Multilingual Matters.

Al-Tabari, Abu-Ja'far (2000). Tafseer al-Tabari: Jaami' al-bayaan 'an ta'weel al-Quran (24 vols). Medina, Saudi Arabia: Mu'assasat al-Risaalah.

Ali, Abdullah Yusuf. (1983). The holy Quran: text, translation and commentary. Maryland: Amana Corporation.

Ali, A. A. M. (2006). Word repetition in the Quran - translating form or Meaning? Journal of King Saud University, Language and Translation, 19, 17-34.

Ali, A. A. M. (1998): Measuring and weighing terms in the Qur'an: their meaning with reference to six English translations. PhD Thesis (unpublished), Durham University.

AL-Hilali, M. \& Khan, M. (1983). Translation of the meaning of the noble Quran in the English language. Madina, Saudi Arabia: King Fahad Complex. 
Akbar, M. (1967). The Meaning of the Quran. Lahore: Islamic Publications.

Al-Mu'jam al-Waseet: Arabic-Arabic Dictionary. (2004). Arab Language Academy, Cairo: Maktabat al-Shurooq ad-Dawliyyah.

Al-Munjid (Arabic Dictionary). (1986). Beirut: Dar al-Mashriq.

Al-Qurtubi, Ahmad ibn 'Abd Allah. (1997). Muqaddimat tafseer al-Imaam al-Qurtubi. Beirut: Daar Ibn Hazm lil-Tibaa'ah wa-l-Nashr wa-1-Tawzee'.

Arberry, A. J. (1980). The Koran interpreted. Oxford: Oxford University Press.

Asad, M. (1980). The message of the Quran. Pennsylvania: Noblebook.

Aziz Y. (1998). Topics in translation with special reference to English and Arabic. Benghazi: University of Garyounis.

Ba'albaki, R. (2005). Al-Mawrid Arabic-English dictionary. Beirut: Dar el-Ilm Lilmalayin.

Baker, Mona. (1998). Routledge encyclopedia of translation. New York: Routledge.

Beaugrande, Robert-Alain de and Wolfgang Dressler. (1981). Introduction to text linguistics. London: Longman.

Bell, Richard. (1937). The Quran translated with a critical rearrangement of the suras. Edinburgh: Edinburgh University Press.

Bussmann, Hadumod et al. (1998). Routledge dictionary of language and linguistics. London and New York: Routledge.

Catford, John C. (1965). A Linguistic theory of translation. London: Oxford University Press.

Collins English Dictionary. (2010). 30 Rep Anv edition. UK: Harper Collins.

Dastjerdi, Hossein Vahid. ( 2011). A Sacramental wordplay: An investigation of pun translatability in the two English translations of the Quran. Asian Social Science, 7(1), 133-144.

Edmonds, Philip \& Graeme Hirst. (2002). Near-synonymy and lexical choice. Computational Linguistics, 28, 105-144.

Farghal, M. (2010). Isuues in translation between Arabic and English. Kuwait University: Department of English.

Halliday, M. A. K. \& Ruqaiya Hasan. (1976). Cohesion in English. London: Longman.

Halliday, M. A. K. (1985). Functional grammar. 2nd ed, London: Arnold.

Hannouna, Y. (2010). Assessment of translating recurrence in selected texts from the Quran. Trans-kom, 3 (1), 85-113.

Ibn Khatheer, Isma'eel bin Amr. (1993). Tafseer al-Quran and al-Adheem. Vol.4. Beirut: Mu'assasat Al-Kutub al-Thaqaafiyyah.

Ibn-Manzour, M. (1970). Lisaan al-Arab. Cairo: Al-Risaalah Institution.

Irving, T. B. (1985). The Quran. Vermont: Amana Books. 
Johnstone, B. (1991). Repetition in Arabic discourse, paradigms, syntagms, and the ecology of language. Amsterdam/Philadelphia: John Benjamins.

Larson, M. L. (1984). Meaning-based translation: a guide to cross-language equivalence. Lanham, Maryland: University Press of America.

Lyons, J. (1968). Introduction to theoretical linguistics. Cambridge: Cambridge University Press.

Newmark, P. (1981). Approaches to translation.Oxford: Pergamon Press.

Nida, E. A. (1981). Meaning across cultures: A study on Bible translating. American Society of Missiology Series: Orbis Books.

Nida, E. A. (1997). Translation in the information age. In Marian B. Labrum (Ed.), The changing scene in world language (pp. 9- 18). Amesterdam and philadelphia: John Banjamins.

Pickthall, M. (1969). The meanings of the glorious Quran. Maryland: Amana Publications.

Robinson, N. (1996). Discovering the Quran: a contemporary approach to a veiled text. London: SCM Press Ltd.

Shakir. M. (1999). The holy Quran. New York: Tahrike Tarsile Quran.

Shehab, E. (2009). The Problems involved in translating Arabic cognitive synonyms into English. Majallat al-Jaam 'ah al-Islamiyyah, 17 (1), 869-890.

Turner. C. (1998). The Quran interpreted: a new interpretation. Richmond, Surrey: Curzon Press.

\section{Sources}

Ibn Faris, Abul-Hasan (1979), Mu'jam maqaayees al-lugha, ed. Abdul-Salaam Haroon, Cairo: Dar al-Fikr, 6 Vols.

The Quranic Arabic Corpus: Word-by-Word Grammar, from http://corpus.quran.com/ wordbyword.jsp?chapter $=2 \&$ verse $=286(23 / 6 / 2011)$ 